\title{
ANALISA PENGARUH KUALITAS LAYANAN TERHADAP LOYALITAS PELANGGAN DI LAUNDRY 5ASEC SURABAYA
}

\author{
Ellys Cornelia S., Nancy Veronica S. \\ Alumni Program Manajemen Perhotelan, Fakultas Ekonomi, Universitas Kristen Petra \\ Endo Wijaya Kartika, Thomas S. Kaihatu \\ Program Manajemen Perhotelan, Fakultas Ekonomi, Universitas Kristen Petra \\ e-mail: endo@peter.petra.ac.id
}

\begin{abstract}
Abstrak: Dalam dunia industri, loyalitas pelanggan merupakan ukuran keberhasilan dalam usaha pelayanan jasa. Pelanggan akan merasa jauh lebih puas manakala dapat memenuhi kebutuhan konsumen jauh melebihi apa yang diharapkan. Ini sangat bergantung pada kualitas layanan dari pada para staf dalam memberikan pelayanan. Demikian halnya dengan Laundry 5 Asec yang menekankan penilaian keberhasilan pemberian pelayanan pada tamu melalui pendapat pelanggan yang diisi oleh para tamu. Loyalitas pelanggan yang berusaha dicapai oleh Laundry 5Asec Surabaya ini dapat diukur dengan cara menyebarkan kuesioner yang akan diisi oleh konsumen. Pertanyaan dalam kuisioner ini berhubungan erat dengan kualitas layanan karyawan laundry 5 Asec Surabaya dari sudut pandang persepsi loyalitas pelanggan. Hasil jawaban kuesioner ini akan dihitung untuk menentukan seberapa besarkah pengaruh jualitas layanan terhadap loyalitas pelanggan. Dengan mengetahui kualitas layanan laundry 5Asec terkait dengan loyalitas pelanggan, Laundry 5Asec Surabaya dapat mengerti secara lebih mendalam mengenai pandangan pelanggan terhadap kualitas layanan yang diberikan karyawan 5Asec Surabaya dan menentukan strategi yang tepat untuk meningkatkan kinerja di masa mendatang demi mencapai loyalitas pelanggan.
\end{abstract}

Kata kunci: Kualitas layanan, Loyalitas pelanggan.

\begin{abstract}
In hospitality industry, customer loyalty is the measurement of the success of service industry. Customer will be more satisfy when we can fulfill their need more than what he expected. It's depended to staff's sincerity when they give the service. Also happened at Laundry 5Asec Surabaya that point the measurement of success of services to guests from guest comment. Customer loyalty that want to be got by laundry 5Asec Surabaya can be measured by distributing quesionaires which are filled by the customer. All the questions are connected with service quality of laundry 5Asec Surabaya from customer loyalty perception. The answers will be counted to find the number of customer loyalty. By knowing the connection of service quality and customer loyalty, laundry 5Asec Surabaya can understand the customer perception to sevice quality better and make the precise strategies for improving the workmanship in the future to get customer loyalty.
\end{abstract}

Keywords: Service Quality, Customer Loyalty

Jasa laundry adalah suatu badan usaha yang menawarkan jasa dalam hal pencucian pakaian, dengan metode-metode khusus. Kondisi persaingan antar perusahaan, kemajuan teknologi, tahapan perekonomian, dan sejarah masyarakat mendorong terjadinya pengembangan kualitas layanan (service quality). Pada sisi penawaran, banyak perusahaan menawarkan barang atau jasa yang sama, dengan sedikit sekali atau hampir tidak ada perbedaan barang atau jasa antar perusahaan, baik yang berasal dari dalam negeri maupun luar negeri, untuk memenuhi kebutuhan dan atau keinginan konsumen yang sama. Sedangkan kemajuan teknologi telah memberikan peluang bagi inovasi dan pengembangan barang atau jasa secara terus-menerus. Pada saat yang sama, pemasaran dihadapkan pada kondisi masyarakat yang semakin makmur, sehingga menuntut tawarantawaran yang lebih berkualitas. Pada sisi lain, sebagian masyarakat telah atau sedang beralih menjadi masyarakat yang berbasis pengetahuan (knowledge economy and society).

Saat ini, konsep kualitas layanan telah menjadi faktor yang dominan terhadap keberhasilan suatu organisasi. Kualitas pelayanan tidak hanya diadopsi oleh lembaga penyelenggara jasa-jasa komersial, tetapi juga telah merembes ke lembaga-lembaga pemerintahan, yang selama ini resisten terhadap tuntutan kualitas pelayanan publik yang prima 
(Sulistyani, 2001, p. 92). Pada prinsipnya, setiap perusahaan harus mampu memuaskan dan mempertahankan pelanggan. Hal ini adalah kunci untuk mempertahankan kinerja bisnis. Dengan memberikan kepada pelanggan " No reason to switch and every reason to stay " berarti perusahaan telah mengisolasi (insulat) mereka dari tekanan kompetisi (Johnson \& Gustafsson, 2000, p.121). Para pemasar tahu bahwa "Having customer, not merely acquiring customers" merupakan hal terpenting bagi perusahaan (Keaveney, 1995, p.150). Oleh karena itu tidak mengherankan jika kepuasan pelanggan total (total customer satisfaction) menjadi tujuan utama (dominan goal) dari perusahaan-perusahaan yang inovatif. Bahkan seringkali sebagai kegiatan bisnis (Cespedes, 1995, p.243; Seybold, et.al.,2001, p.3). Maka, tidak mengherankan apabila sejak tahun 1980-an, loyalitas pelanggan merupakan acuan dalam dunia bisnis (Griffin,1995, p.1; Witt \& Moutinho, 1994, p. 279). Loyalitas pelanggan menjadi bagian integral dari revolusi kualitas (Peter \& Waterman Jr., 1982, p.135). Barlaw dan Maul ,2000, p.24 menyatakan bahwa: "produksilah dengan kualitas tertinggi dan anda akan mendapatkan pelanggan yang loyal" telah menjadi mantra di tahun 80-an. Sehingga dampaknya , loyalitas pelanggan menjadi area studi terbesar dalam pemasaran. Selama kurang lebih dua puluh tahun, lebih dari 15.000 artikel akademis maupun bisnis telah dipublikasikan (Hoffman\&Bateson,1997, p.269).

Akan tetapi, di era 90-an, memuaskan pelanggan saja tidaklah memadai. Sebab, hanya pelanggan yang benar-benar puas saja (delight) yang akan loyal (Kotler, 2000, p.113; Burns, et.al., 2000, p.22; Schneider \& Bowen, 1999, p.79; Bhote, 1996, p.87). Delight telah menjadi konstruk yang berbeda (ingin dibedakan) dengan kepuasan (Raut, 2002, p.67). Jones dan Sasser Jr., 1997, p.88, menyatakan bahwa pelanggan yang puas, tapi tidak benar-benar puas ternyata juga menyatakan rasa tidak senangnya terhadap beberapa aspek dari suatu produk. Konsekuensinya, perilaku pindah (switching behavior) dapat terjadi setiap saat (Reichheld, 1996, p. 331). Secara teoritis, menurut Deming dalam buku " Out of the Crisis", perpindahan tersebut dapat terjadi apabila pelanggan merasa tidak rugi terlalu banyak atau bahkan mungkin mendapatkan produk yang lebih baik (Kennedy, 1996, p. 224). Dengan demikian, kunci agar perusahan tetap eksis adalah kemampuan perusahaan untuk mempertahankan pelanggannya. Apabila pelanggan pergi, maka eksistensi perusahaan tidak diperlukan lagi, dan sebaliknya (Seybold, et.al., 2001, p. 90; Cespedes, 1995 , p. 49). Oleh karena itu perusahaan perlu mendeteksi sikap pelanggannya. Pemahaman pemasar terhadap sikap pelanggan, dapat membantu pemasar untuk dapat mempengaruhi dan mengubah sikap konsumen ke arah yang positif.

Setiap bisnis memiliki tugas yang kuat untuk menciptakan Loyalitas Pelanggan, sebab seperti yang ditulis oleh Kaset International "Another reason for the importance of building customer loyalty is a statistic that says it costs five times as much to get a new customer as it does to keep an old one". yang diartikan, dalam membangun sebuah loyalitas konsumen itu sangatlah sulit, apabila kita sudah mendapatkan konsumen yang loyal, kita harus mempertahankan dengan segala cara. Karena mempertahankan konsumen lama lima kali lebih sulit daripada mencari konsumen yang baru. Hasil penilaian konsumen atas kualitas layanan akan membentuk pola loyalitas konsumen tertentu (Consumer Loyalty Pattern), yaitu dari sangat loyal sampai dengan sangat tidak loyal. (Kotler, 1994, p.262). Konsumen dikatakan loyal bila ia mempunyai pola konsumsi terhadap satu layanan pada setiap waktu dan tidak pernah berganti dari satu layanan ke layanan yang lain, tingkat ini menunjukkan loyalitas yang sangat tinggi. Pada sisi lain, konsumen disebut sangat tidak loyal bila konsumen sama sekali tidak memiliki loyalitas pada layanan tertentu. Konsumen semacam ini setiap waktu memiliki pola konsumsi yang berubah-ubah dari satu layanan ke layanan lainnya.

Dalam kesempatan ini, penulis akan menganalisa mengenai "Analisa Pengaruh Kualitas Layanan terhadap Loyalitas Pelanggan Laundry 5asec Surabaya". Penulis membahas masalah ini dikarenakan pada kenyataannya sekarang ini semakin menjamurnya laundry di kalangan masyarakat, mulai dari laundry besar seperti 5Asec, hingga laundrylaundry kecil. 5asec pertama kali berdiri di Prancis, mulai tahun 1968 dan terus mengibarkan sayap kejayaannya di bidang laundry dan dry-cleaning. Sekarang 5asec telah berdiri di beberapa Negara, serta memiliki outlet hampir di seluruh dunia. Di Surabaya sendiri 5asec sudah berdiri di 2 Surabaya bagian, yaitu Surabaya Timur dan Surabaya Barat.

Penulis membatasi seluruh aspek yang mempengaruhi loyalitas pelanggan di laundry 5asec, hingga menjadi aspek yang paling mendasar, yaitu kualitas layanan. 5asec selalu memperhatikan kualitas layanan dalam melayani para pelanggannya, dengan cara memberikan banyak kemudahan bagi para pelanggannya.

\section{Konsep Kualitas Layanan}

Menurut Hutabarat (1997), Kualitas layanan adalah "senjata ampuh dalam keunggulan perusahaan, 
terutama perusahaan jasa. Penelitian PIMS (Profit Impact at Market Strategy) menunjukkan adanya korelasi kuat antara kualitas pelayanan yang diterima pelanggan dengan pangsa pasar." (p.68). Hasil penelitian ini menunjukkan bahwa salah satu faktor yang mempengaruhi pangsa pasar adalah peningkatan kualitas layanan. Kualitas layanan menjadi pemicu keberhasilan perusahaan pada segala lini. Kualitas layanan merupakan kewajiban bagi perusahaan, baik perusahaan manufaktur maupun (terutama) perusahaan jasa. Heskett, pakar pemasaran, menyatakan, "Whatever your business, service have something to teach" (Hutabarat, 1997, p. 72). Kualitas layanan merupakan kunci sukses, sehingga kualitas layanan harus menjadi fokus perhatian manajemen perusahaan ketika menjalankan bisnisnya. "Layanan yang berkualitas dan memuaskan pelanggan perlu dilakukan terus - menerus, meskipun pengaduan yang diterima relatif rendah. Sekitar 95\% konsumen yang tidak puas memilih untuk tidak melakukan pengaduan, tetapi sebagian besar cukup menghentikan pembeliannya." (Kotler, 1997, p. 99).

Philip Kotler (2000), mengatakan "bahwa sebuah perusahaan jasa dapat memenangkan persaingan dengan menyampaikan secara konsisten layanan yang bermutu lebih tinggi dibandingkan para pesaing dan yang lebih tinggi dari pada harapan pelanggan.” Harapan-harapan itu dibentuk oleh pengalaman di masa lalu, pembicaraan dari mulut ke mulut, dan iklan perusahaan jasa. Setelah menerima jasa itu, pelanggan membandingkan jasa yang dialami dengan jasa yang diharapkan. Jika jasa yang dialami berada dibawah jasa yang diharapkan, pelanggan tidak berminat lagi terhadap penyedia jasa itu. Jika jasa yang dialami memenuhi atau melebihi harapan, mereka akan menggunakan penyedia jasa itu lagi. (p. 177)

Pasuraman, Zeithaml, dan Berry (1990), "membentuk model mutu jasa yang menyoroti syaratsyarat utama dalam memberikan mutu jasa yang tinggi." (p. 232). Dalam model ini mengidentifikasi lima kesenjangan yang mengakibatkan kegagalan penyampaian jasa, yaitu : kesenjangan antara harapan konsumen dan persepsi manajemen dimana manajemen tidak selalu memahami secara tepat apa yang diinginkan pelanggan, kesenjangan antara persepsi manajemen dengan spesifikasi mutu jasa dimana manajemen mungkin memahami secara tepat keinginan pelanggan tetapi tidak menetapkan satu kumpulan standar kinerja tertentu, kesenjangan antara spesifikasi mutu jasa dan penyampaian jasa dimana penyedia jasa mungkin kurang terlatih, tidak mampu atau tidak memenuhi standar, kesenjangan antara penyampaian jasa dan komunikasi eksternal dimana harapan konsumen dipengaruhi oleh pernyataan yang dibuat perusahaan dan iklan perusahaan, serta kesenjangan antara jasa yang dialami dan jasa yang diharapkan dimana kesenjangan ini terjadi bila pelanggan memiliki persepsi yang keliru tentang mutu jasa yang disampaikan.

Cornell (1984) merekomendasikan bahwa "industri jasa membutuhkan pengertian yang luas tentang kualitas yang kemudian banyak digunakan untuk industri manufaktur" (p.114). Zimmerman (1985) mengambil konsep "quality control yang diperoleh dari industri manufaktur dan kemudian diterapkan dalam kualitas pelayanan (service quality). Zimmerman juga menyebutkan bahwa komponen dari kualitas layanan meliputi : practicality, replikasi dari kemampuan manufaktur, immediacy, ultimate user satisfaction, dan standard korespondensi" (p.89). Menurut konsep Pasuraman (1985) dan Zeithaml (1988), konsumen melihat proses pembentukan kualitas layanan sebagai pemberdayaan atribut interior dan eksterior dari kualitas produksi atau kualitas layanan level bawah, melalui perbandingan unit - unit internal dan merupakan proses dalam membangun level yang lebih tinggi dari kualitas pelayanan yang diterima (perceived service quality).

Kualitas layanan sangat dibutuhkan terutama di industri jasa mengingat konsumennya mempunyai keinginan yang selalu ingin dipenuhi dan dipuaskan. Konsumen selalu mengharapkan untuk mendapatkan pelayanan yang maksimal dari para penyedia jasa dalam hal ini mereka ingin diperlakukan secara profesional serta memperoleh sesuatu sesuai dengan yang mereka harapkan. Tantangan utama yang dihadapi oleh industri jasa dalam hal ini jasa laundry adalah bagaimana memadukan kualitas layanan yang prima dengan apa yang diharapkan konsumen. Kualitas layanan merupakan salah satu faktor yang mendukung tercapainya customer loyalty karena dengan adanya layanan yang baik akan membuat para pelanggan merasa nyaman dan dihargai.

Dalam riset awal Parasuraman, Zeithaml, dan Berry (1985 : p.155) meneliti sejumlah industri jasa (seperti perbankan, jasa kartu kredit, reparasi, dan pemeliharaan, serta jasa telpon interlokal ), dan berhasil mengidentifikasi sepuluh dimensi pokok kualitas layanan, yaitu: (1) Reliabilitas,(2) Responsivitas atau daya tanggap, (3) Kompetensi, (4) Akses, (5) Kesopanan (courtesy), (6) Komunikasi, (7) Kredibilitas, (8) Keamanan, (9) Kemampuan memahami pelanggan, (10) Bukti fisik (tangibles). Kemudian dilakukan riset kembali pada tahun 1988, dan mereka menemukan adanya overlapping diantara beberapa dimensi diatas. Oleh sebab itu, mereka menyederhanakan sepuluh dimensi diatas menjadi lima dimensi pokok. Kompetensi, kesopanan, 
kredibilitas dan keamanan dijadikan satu sub menjadi jaminan (assurance). Sedangkan akses, komunikasi, dan kemampuan memahami pelanggan diintegrasikan menjadi empati (emphaty).

Terdapat lima dimensi utama yang disusun sesuai urutan tingkat kepentingan relatifnya sebagai berikut:

- Reliabilitas (reliability), berkaitan dengan kemampuan perusahaan untuk menyampaikan layanan yang dijanjikan secara akurat sejak pertama kali. Sebagai contoh, sebuah pelanggan barangkali memilih jasa laundry, semata-mata hanya berdasarkan ketenaran nama. Apabila laundry tersebut mampu memberikan apa yang dimintai oleh pelanggan, pelanggan tersebut akan puas dan akan kembali lagi. Namun, bila jasa laundry tersebut tidak dapat memenuhi apa yang diharapkan pelanggan, maka pelanggan menjadi tidak puas dan tidak akan kembali lagi ke laundry tersebut.

- Daya Tanggap (responsiveness), berkenaan dengan kesediaan dan kemampuan penyedia layanan untuk membantu para pelanggan dan merespons permintaan mereka dengan segera. Pernah menelpon layanan jasa cuci laundry? Berapa lama harus menunggu sebelum akhirnya ada yang menjawab telepon? Apakah anda dilayani mesin penjawab? Apakah anda dipingpong ke sana ke mari sebelum akhirnya dibantu ?

- Jaminan (assurance), berkenaan dengan pengetahuan dan kesopanan karyawan serta kemampuan mereka dalam menumbuhkan rasa percaya (trust) dan keyakinan pelanggan (confidence). Bila anda ingin menggunakan jasa cuci laundry, Anda tentu saja ingin mendapat jaminan bahwa perusahaan laundry yang melayani anda benar-benar kompeten.

- Empati (emphaty), berarti bahwa perusahaan memahami masalah para pelanggannya dan bertindak demi kepentingan pelanggan, serta memberikan perhatian personal kepada para pelanggan dan memiliki jam operasi yang nyaman.

- Bukti fisik (tangibles), berkenaan dengan penampilan fisik fasilitas layanan, peralatan/ perlengkapan, sumber daya manusia, dan materi komunikasi perusahaan. Perusahaan laundry yang berfokus melayani pelanggan elit bakal berinvestasi pada dekorasi dan pencahayaan laundry serta mempekerjakan karyawan yang berpenampilan menarik dan rapi. Meskipun penampilan menarik dan rapi tidak berpengaruh terhadap layanan yang diberikan; klien bisa saja meyakini bahwa laundryannya pasti akan ditata rapi oleh para karyawannya.

\section{Konsep Loyalitas Konsumen}

Kesetiaan konsumen tidak terbentuk dalam waktu singkat tetapi melalui proses belajar dan berdasarkan hasil pengalaman dari konsumen itu sendiri dari pembelian konsisten sepanjang waktu. Bila yang didapat sudah sesuai dengan harapan, maka proses pembelian ini terus berulang. Hal ini dapat dikatakan bahwa telah timbul adanya kesetiaan konsumen. Bila dari pengalamannya, konsumen tidak mendapatkan merek yang memuaskan maka ia tidak akan berhenti untuk mencoba merek-merek yang lain sampai ia mendapatkan produk atau jasa yang memenuhi kriteria mereka.

Loyalitas merupakan besarnya konsumsi dan frekuensi pembelian dilakukan oleh seorang konsumen terhadap suatu perusahaan (Wulf, Gaby dan Lacobucci ,2001). Dan mereka berhasil menemukan bahwa kualitas keterhubungan yang terdiri dari kepuasan, kepercayaan dan komitmen mempunyai hubungan yang positif dengan loyalitas. Pelanggan yang puas dan loyal (setia) merupakan peluang untuk mendapatkan pelanggan baru. Mempertahankan semua pelanggan yang ada umumnya akan lebih menguntungkan dibandingkan dengan pergantian pelanggan karena biaya untuk menarik pelanggan baru bisa lima kali lipat dari biaya mempertahankan seorang pelanggan yang sudah ada (Kotler et al, 2000 : p. 60). Jadi mempertahankan pelanggan sama dengan mempertahankan kelangsungan hidup perusahaan sehingga akan dapat meningkatkan loyalitas.

Menurut Kotler, Bowen dan Makens definisi dari customer loyalty " How likely customer are to return and their willingmess to perform partnershipping activities for the organization" (1999, p.351). Yang artinya sebagaimana pembeli supaya dapat kembali dan ada kemauan untuk menjadi bagian dari organisasi itu. Adapun juga definisi customer loyalty menurut Johnson (1997, p.41) yaitu "Customer loyalty is a predisposition toward purchasing and or using a particular product, manufacturer or service provider again." Yang artinya dapat dikatakan bahwa loyalitas konsumen adalah suatu kecenderungan untuk membeli dan atau menggunakan lagi suatu produk atau jasa. Hal terpenting yang harus dilakukan untuk memenangkan persaingan adalah memuaskan konsumen.

Perusahaan yang berhasil menjaga agar konsumennya selalu puas akan lebih mudah untuk mempertahankan bahkan mengembangkan usahanya karena konsumennya lebih setia, sehingga konsumen tersebut kerap kali melakukan pembelian ulang dan rela membayar lebih. (Johnson, 1997, p.41). Menurut 
Kotler dan Armstrong (1996 : 554) bahwa "loyalitas berasal dari pemenuhan harapan konsumen, sedangkan ekspektasi berasal dari pengalaman pembelian terdahulu oleh konsumen, opini dari teman dan kerabat dan janji atau informasi dari pemasar atau pesaing". Menurut Kapferer \& Laurent (1993), dikutip dalam Odin, et al. 2001), "loyalitas pelanggan didefinisikan perilaku pembelian ulang ( repeat purchasing behavior) merupakan konsep multidimensional yang kompleks".

Dalam mengukur loyalitas, Zeithaml et al (1996:38) menyatakan dengan beberapa atribut yaitu:

1) mengatakan hal yang positif tentang perusahaan kepada orang lain;

2) merekomendasikan perusahaan kepada orang lain yang meminta saran;

3) mempertimbangkan bahwa perusahaan merupakan pilihan pertama dalam melakukan pembelian jasa;

4) melakukan lebih banyak bisnis atau pembelian dengan perusahaan beberapa tahun mendatang. Adapun pendapat dari Oliver (1999:53) yang mendefinisikan "loyalitas konsumen dengan suatu keadaan dimana terdapat komitmen yang kuat dalam pembelian ulang dan penggunaan kembali barang dan jasa perusahaan".

Untuk itu terdapat konsep loyalitas yang ditawarkan Oliver (1999:35-37) mengenai tingkat loyalitas konsumen terdiri dari empat tahap yakni:

- Loyalitas Kognitif

Tahap dimana pengetahuan langsung maupun tidak langsung konsumen akan merek, dan manfaatnya, dan dilanjutkan ke pembelian berdasarkan pada keyakinan akan superioritas yang ditawarkan. Pada tahap ini dasar kesetiaan adalah informasi tentang produk atau jasa yang tersedia bagi konsumen.

- Loyalitas Afektif

Sikap favorable konsumen terhadap merek yang merupakan hasil dari konfirmasi yang berulang dari harapannya selama tahap cognitively loyalty berlangsung. Pada tahap ini dasar kesetiaannya adalah pada sikap dan komitmen konsumen terhadap produk dan jasa sehingga pada tahap ini telah terbentuk suatu hubungan yang lebih mendalam antara konsumen dengan penyedia produk atau jasa dibandingkan pada tahap sebelumnya.

- Loyalitas Konatif

Intensi membeli ulang sangat kuat dan memiliki keterlibatan tinggi yang merupakan dorongan motivasi.
- Loyalitas Tindakan

Menghubungkan penambahan yang baik untuk tindakan serta keinginan untuk mengatasi kesulitan seperti pada tindakan kesetiaan.

\section{Hubungan Antar Konsep}

Hampir keseluruhan pengusaha bisnis laundry, melakukan segala cara untuk menarik minat dari konsumennya, semula dari konsumen yang biasa saja hingga menjadi konsumen yang loyal terhadap laundry tersebut. Pengusaha bisnis laundry selalu memberikan yang terbaik, yaitu menjaga dan meningkatkan selalu kualitas layanan.

Dalam hal ini penulis menganalisa hubungan antara kualitas layanan dengan pengaruhnya terhadap customer loyalty. Adapun analisa tersebut secara model penelitian seperti pada Gambar 1.

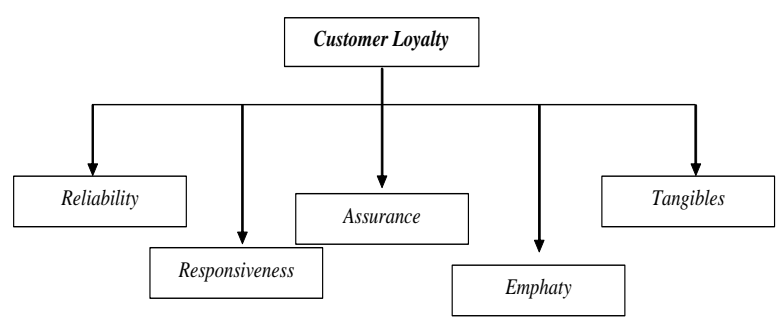

Gambar 1. Hubungan Antar Konsep

Hubungan Reliability terhadap loyalitas pelanggan

Menurut Parasuraman dalam Tjiptono, (2008, p. 95) bahwa "indikator dari reliability terdiri dari konsistensi kerja (performance) dan sifat terpercaya (dependability) yang positif berpengaruh langsung dengan dimensi loyalitas pelanggan yaitu menyatakan hal yang positif (say positive things), memberikan rekomendasi kepada orang lain (recommend friend) dan melakukan pembelian terus menerus (continue purchasing)".

\section{Hubungan Responsiveness terhadap loyalitas pelanggan}

Menurut Parasuraman dalam Tjiptono, (2008, p.95) bahwa "responsiveness yaitu kesediaan dan kesigapan para karyawan untuk membantu dan melayani pelanggan dengan segera berpengaruh secara langsung secara positif terhadap loyalitas pelanggan. Karena memberikan nilai plus berupa motivasi khusus bagi para pelanggan untuk menjalin ikatan relasi saling menguntungkan dalam jangka panjang dengan perusahaan. Ikatan inilah yang akan membuat pelanggan menjadi loyal". 
Hubungan Assurance terhadap loyalitas pelanggan

Menurut Parasuraman dalam Tjiptono, (2008, p. 95) “assurance berkenaan dengan pengetahuan dan personality karyawan, serta kemampuan mereka dalam menumbuhkan rasa percaya (trust) dan keyakinan pelanggan (confidence), memberikan kontribusi positif terhadap terwujudnya loyalitas pelanggan. Karena dengan beberapa hal tadi, pelanggan merasa dimengerti dan akhirnya merasa nyaman, sehingga membuat pelanggan tersebut menjadi loyal".

\section{Hubungan Emphaty terhadap loyalitas pelanggan}

Menurut Parasuraman dalam Tjiptono, (2008, p 95) "emphaty berarti perusahaan memahami masalah pelanggannya dan bertindak demi kepentingan pelanggan, berpengaruh secara positif dimensi loyalitas pelanggan yaitu tetap memilih merek tersebut, merekomendasikannya kepada orang lain dan melakukan pembelian ulang".

\section{Hubungan Tangibles terhadap loyalitas pelanggan}

Menurut Parasuraman dalam Tjiptono, (2008, p. 95) "tangibles berkenaan dengan penampilan fisik fasilitas layanan, peralatan/perlengkapan, sumber daya manusia, dan materi komunikasi perusahaan, berkaitan secara langsung dengan indicator-indikator loyalitas pelanggan".

\section{Kerangka Pemikiran}

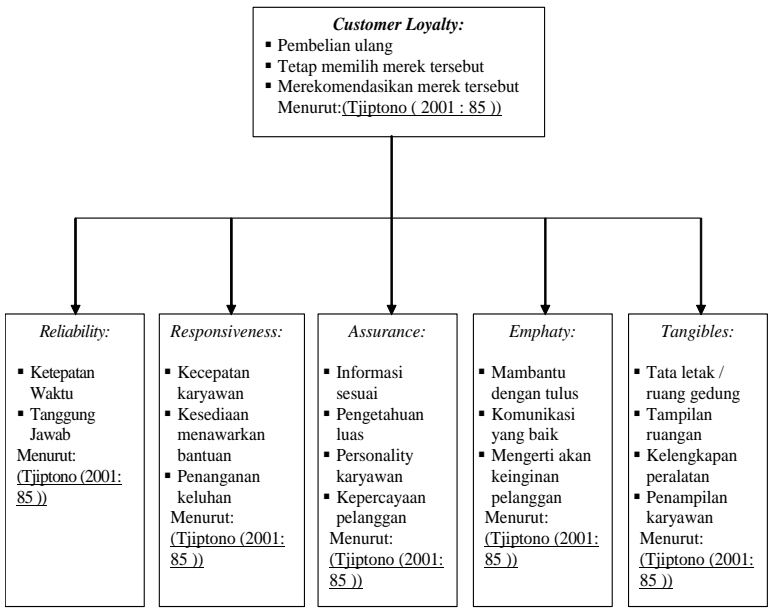

Gambar 2. Kerangka Pemikiran

\section{HIPOTESA}

Adapun hipotesa dalam penelitian ini ialah:

- H1 : Diduga variabel reliability, responsiveness, assurance, emphaty, dan tangibles berpengaruh secara serempak dan signifikan terhadap loyalitas pelanggan laundry 5 asec di Surabaya.

- H2 : Diduga variabel resposiveness berpengaruh paling dominan terhadap loyalitas pelanggan laundry 5asec di Surabaya.

\section{METODOLOGI PENELITIAN}

\section{Jenis Penelitian, Populasi, dan Sampel}

Jenis penelitian yang digunakan adalah penelitian kuantitatif kausal. Penelitian kuantitatif kausal adalah penelitian pendekatan ilmiah terhadap pengambilan keputusan manajerial dan ekonomi yang bertujuan untuk mendaptkan bukti hubungan sebab-akibat atau pengaruh dari variabel-variabel penelitian. Peneliti melakukan pengamatan terhadap konsekuensikonsekuensi yang timbul dan menelusuri kembali fakta yang secara masuk akal sebagai faktor-faktor penyebabnya. Peneliti dapat mengidentifikasi fakta atau peristiwa tersebut sebagai variabel yang dipengaruhi (variable dependen) yaitu customer loyalty. Dan melakukan penyelidikan terhadap variabel-variabel yang mempengaruhi (variable indipenden) yaitu kualitas layanan.

Dalam penelitian ini penulis menggunakan metode kuanitatif karena pengumpulan data, penafsiran data, dan penarikan kesimpulan dari penelitian ini berupa angka. Dalam penelitian ini penulis melakukan perhitungan mean dan distribusi frekuensi untuk memberikan gambaran dari data yang akan diperoleh.

"Populasi adalah keseluruhan obyek atau item yang dibatasi oleh kriteria tertentu" (Abdul Hakim, 1997, p.18). Populasi yang ditetapkan dalam penelitian ini adalah seluruh pengunjung 5Asec. "Sampel adalah kumpulan sebagian anggota populasi yang terbentuk karena sampling" (Abdul Hakim, 1997, p.18).

Batasan dalam pengambilan sampel adalah:

1. Orang-orang yang pernah berkunjung dan menggunakan jasa laundry 5Asec, sebanyak minimal 2 kali, selama 6 bulan terakhir.

2. Batas lingkupnya hanya jasa cuci 5 Asec di Kota Surabaya.

Populasi dan sampel dalam penelitian ini merupakan sumber data, artinya sifat-sifat atau karakteristik dari sekelompok subyek, gejala, dan obyek. Sifat dan jaringan tersebut dijaring melalui instrument yang telah dipilih dan dipersiapkan oleh peneliti. Populasi tidak terbatas luasnya, bahkan ada yang tidak dapat dihitung jumlah dan besarannya sehingga tidak mungkin diteliti. Kalaupun akan diteliti, akan memerlukan biaya yang relatif cukup banyak, tenaga yang besar, waktu yang lama, dan sangat tidak praktis. 
Oleh karena itu, sebagian saja asal memiliki sifatsifat yang sama dengan populasi. Proses menarik sebagian subyek, gejala,atau obyek yang ada pada populasi tersebut disebut sampel atau penyampelan. Dengan demikian penelitian dilakukan terhadap sampel, tetapi hasilnya dapat menafsirkan populasi (sifat-sifat dan karakteristiknya). Mengingat luasnya populasi, peneliti bisa membatasi populasi sehingga mudah dalam menarik sampel. Pembatasan populasi dilakukan dengan membedakan populasi sasaran (target population) dan populasi terjangkau (accessible population). Sampel ditarik dari populasi terjangkau. Dalam penelitian ini, penulis menggunakan Non-Probability Sampling, karena jumlah populasi tidak diketahui kepastiannya.

\section{Definisi Operasional Variabel}

Variabel yang digunakan dalam penelitian ini terdiri dari 2 variabel yaitu variabel bebas (independent variable) dan variabel terikat (dependent variable). Yang dimaksud variabel bebas ialah variabel yang menjadi sebab timbulnya atau berubahnya variabel terikat. Jadi variabel bebas adalah variabel yang mempengaruhi. Variabel terikat merupakan variabel yang dipengaruhi atau yang menjadi akibat, karena adanya variabel bebas. Dalam Penelitian ini variabel bebas yaitu kualitas layanan, yang dilambangkan dengan symbol " $X$ " dan kesetiaan pelanggan atau loyalitas pelanggan sebagai variabel terikat dilambangkan dengan symbol "Y". Berikut akan dijabarkan variabel bebas dan terikat melalui definisi operasional adalah sebagai berikut:

\section{Variabel bebas (independent variabel)}

Variabel bebas yang diteliti terdiri dari variable:

1. Reliabilty (XI)

- Ketepatan waktu pengerjaan karyawan 5asec.

- Adanya tanggung Jawab yang dimiliki oleh karyawan 5 asec

2. Responsiveness $(X 2)$

- Kecepatan karyawan 5asec dalam merespon permintaan pelanggan.

- Kesediaan karyawan 5asec dalam menawarkan bantuan kepada pelanggan.

- Penangan keluhan pelanggan oleh karyawan 5asec.

3. Assurance (X3)

- Informasi yang diberikan para karyawan 5 asec.

- Kualitas pengetahuan karyawan 5asec terhadap produk.

- Personality (kesopanan, keramah-tamahan, dan perhatian) para karyawan 5asec.

- Kepercayaan yang ditanamkan para karyawan 5asec dibenak setiap pelanggan.
○ Kemauan karyawan 5asec dalam membantu pelanggan.

- Komunikasi karyawan dengan pelanggan 5asec

- Kemampuan karyawan 5asec memahami kemauan pelanggan.

5. Tangible (X5)

- Tata letak/ ruang di 5asec.

- Tampilan luar dan dalam 5asec.

- Tersediannya perlengkapan / peralatan laundry 5asec.

○ Penampilan karyawan 5asec.

Variabel tertanggung (dependent variabel)

Variabel tergantung yang diteliti adalah:

1. Loyalitas Konsumen $(\mathrm{Y})$

Adalah merupakan dorongan dan perilaku untuk melakukan pembelian secara berulang-ulang dan untuk membangun kesetiaan pelanggan terhadap sesuatu jasa yang dihasilkan oleh badan usaha membutuhkan waktu yang lama melalui suatu proses pembelian berulang-ulang tersebut. Menurut Parasuraman, et all (1998) dalam buku 10 prinsip Kepuasan Pelanggan (2008:57-73), indicator empiriknya, ialah:

- Pembelian ulang pelanggan 5 asec.

- Pelanggan tetap memilih laundry 5asec.

- Merekomendasikan laundry 5asec kepada orang lain.

\section{Teknik Analisis Data}

Untuk perhitungan kuantitatif dalam penelitian ini, teknik analisa data yang digunakan adalah Analisa Regresi Berganda, Koefisien Korelasi Berganda (R), Uji F, dan Uji t.

\section{HASIL DAN PEMBAHASAN}

\section{Deskripsi Profil Responden}

Berikut adalah deskripsi profil responden yang meliputi jenis kelamin, usia, status, pekerjaan, pendapatan per bulan, serta frekuensi menggunakan jasa Laundry 5Asec dalam 6 bulan terakhir.

$\underline{\text { Jenis Kelamin }}$

Tabel 1. Profil Responden Berdasarkan Jenis Kelamin

\begin{tabular}{ccc}
\hline Jenis Kelamin & Frekuensi & Prosentase \\
Perempuan & 56 & 56.0 \\
Laki-Laki & 44 & 44.0 \\
\hline Total & 100 & 100.0 \\
\hline
\end{tabular}

Sumber: Lampiran 5

4. Emphaty (X4) 
Berdasarkan Tabel 1 dapat dilihat bahwa mayoritas responden adalah perempuan yaitu sebanyak 56 responden atau $56 \%$, sedangkan responden laki-laki sebanyak 44 responden atau $44 \%$.

Usia

Tabel 2. Profil Responden Berdasarkan Usia

\begin{tabular}{ccc}
\hline Usia & Frekuensi & Prosentase \\
\hline$<20$ tahun & 1 & 1.0 \\
$21-30$ tahun & 44 & 44.0 \\
$31-40$ tahun & 34 & 34.0 \\
$41-50$ tahun & 20 & 20.0 \\
$>50$ tahun & 1 & 1.0 \\
\hline Total & 100 & 100.0 \\
\hline
\end{tabular}

Sumber: Lampiran 5

Berdasarkan Tabel 2 dapat dilihat bahwa mayoritas responden berusia antara 21 hingga 30 tahun yaitu sebanyak 44 responden atau $44 \%$. Sebanyak 34 responden atau $34 \%$ berusia antara 31 hingga 40 tahun, dan sebanyak 20 responden atau $20 \%$ berusia antara 41 hingga 50 tahun, sedangkan responden yang berusia kurang dari 20 tahun hanya 1 orang atau $1 \%$ dan terdapat 1 orang atau $1 \%$ yang berusia di atas 50 tahun.

\section{$\underline{\text { Status }}$}

Tabel 3. Profil Responden Berdasarkan Status

\begin{tabular}{ccc}
\hline Status & Frekuensi & Prosentase \\
\hline Belum Menikah & 36 & 36.0 \\
Sudah Menikah & 64 & 64.0 \\
\hline Total & 100 & 100.0 \\
\hline Sumber: Lampiran 5 & &
\end{tabular}

Berdasarkan Tabel 3 dapat dilihat bahwa mayoritas responden mempunyai status sudah menikah yaitu sebanyak 64 responden atau 64\%, sedangkan responden yang mempunyai status belum menikah sebanyak 36 responden atau $36 \%$.

\section{$\underline{\text { Pekerjaan }}$}

Tabel 4. Profil Responden Berdasarkan Usia

\begin{tabular}{lcc}
\hline \multicolumn{1}{c}{ Pekerjaan } & Frekuensi & Prosentase \\
\hline Pelajar/Mahasiswa & 26 & 26.0 \\
Wiraswasta & 29 & 29.0 \\
Pegawai Negeri & 16 & 16.0 \\
Pegawai Swasta & 10 & 10.0 \\
Professional & 5 & 5.0 \\
Lainnya & 14 & 14.0 \\
\hline \multicolumn{1}{c}{ Total } & 100 & 100.0 \\
\hline
\end{tabular}

Sumber: Lampiran 5
Berdasarkan Tabel 4 dapat dilihat bahwa mayoritas responden berprofesi sebagai wiraswasta yaitu sebanyak 29 responden atau 29\%. Sebanyak 26 responden atau $26 \%$ berprofesi sebagai pelajar/ mahasiswa, sebanyak 16 responden atau $16 \%$ berprofesi sebagai pegawai negeri, sebanyak 10 responden atau $10 \%$ berprofesi sebagai pegawai swasta, dan sebanyak 5 responden atau $5 \%$ berprofesi sebagai tenaga professional, sedangkan responden yang mempunyai pekerjaan lainnya sebanyak 14 orang atau $14 \%$.

\section{$\underline{\text { Pendapatan Per Bulan }}$}

Tabel 5. Profil Responden Berdasarkan Pendapatan Per Bulan

\begin{tabular}{lcc}
\hline \multicolumn{1}{c}{ Pendapatan Per Bulan } & Frekuensi & Prosentase \\
\hline Rp. 1.000.000 - Rp. 4.999 .999 & 49 & 49.0 \\
Rp. 5.000.000 - Rp. 9.999 .999 & 17 & 17.0 \\
>=Rp. 10.000.000 & 34 & 34.0 \\
\hline Total & 100 & 100.0 \\
\hline
\end{tabular}

Sumber: Lampiran 5

Berdasarkan Tabel 5 dapat dilihat bahwa mayoritas responden mempunyai pendapatan per bulan antara Rp. 1.000.000 hingga Rp. 4.999.999 yaitu sebanyak 49 responden atau $49 \%$. Sebanyak 17 responden atau $17 \%$ mempunyai pendapatan per bulan antara Rp. 5.000.000 hingga Rp. 9.999.999, dan sebanyak 34 responden atau 34\% mempunyai pendapatan per bulan Rp. 10.000.000 ke atas, sedangkan responden yang mempunyai pendapatan per bulan kurag dari Rp. 1.000.000 tidak ada.

Frekuensi Menggunakan Jasa Laundry 5Asec Dalam $\underline{6 \text { Bulan Terakhir }}$

Tabel 6. Profil Responden Berdasarkan Frekuensi Menggunakan Jasa Laundry 5Asec Dalam 6 Bulan Terakhir

\begin{tabular}{lcc}
\hline \multicolumn{1}{c}{ Frekuensi } & Frekuensi & Prosentase \\
\hline$<=5$ kali & 54 & 54.0 \\
$6-10$ kali & 24 & 24.0 \\
$11-15$ kali & 13 & 13.0 \\
$>=16$ kali & 9 & 9.0 \\
\hline \multicolumn{1}{c}{ Total } & 100 & 100.0 \\
\hline
\end{tabular}

Sumber: Lampiran 5

Berdasarkan Tabel 6 dapat dilihat bahwa mayoritas responden dalam 6 bulan terakhir menggunakan jasa Laundry 5 Asec sebanyak 5 kali atau kurang dari 5 kali yaitu 54 responden atau $54 \%$. Sebanyak 24 responden atau 24\% dalam 6 bulan terakhir menggunakan jasa Laundry 5Asec antara 6 
hingga 10 kali, dan sebanyak 13 responden atau $13 \%$ dalam 6 bulan terakhir menggunakan jasa Laundry 5Asec antara 11 hingga 15 kali, sedangkan responden yang dalam 6 bulan terakhir menggunakan jasa Laundry 5Asec 16 kali atau lebih hanya 9 orang atau $9 \%$.

\section{Deskripsi Tanggapan Responden}

Berikut adalah deskripsi tanggapan responden mengenai variable bebas penelitian yaitu reliability, responsiveness, assurance, emphaty dan tangibles, serta mengenai loyalitas pelanggan sebagai variabel terikat.

\section{$\underline{\text { Reliability }\left(\mathrm{X}_{1}\right)}$}

Tabel 7. Tanggapan Responden Mengenai Reliability

\begin{tabular}{|c|c|c|c|c|c|c|}
\hline \multirow{3}{*}{ Indikator } & \multicolumn{5}{|c|}{ Skor Jawaban } & \multirow{3}{*}{ Total } \\
\hline & \multirow{2}{*}{$\begin{array}{c}1 \\
\text { STJ }\end{array}$} & \multirow{2}{*}{$\begin{array}{c}2 \\
\text { TS } \\
\end{array}$} & \multirow{2}{*}{$\begin{array}{c}3 \\
K S \\
\end{array}$} & \multirow{2}{*}{$\begin{array}{l}4 \\
S \\
\end{array}$} & \multirow{2}{*}{$\begin{array}{c}5 \\
\text { SS } \\
\end{array}$} & \\
\hline & & & & & & \\
\hline $\begin{array}{l}\text { Karyawan 5Asec selalu tepat } \\
\text { waktu }\end{array}$ & 3 & 6 & 23 & 44 & 24 & 100 \\
\hline $\begin{array}{l}\text { Karyawan } 5 \text { Asec selalu } \\
\text { bertanggung jawab terhadap } \\
\text { pekerjaan }\end{array}$ & 0 & 9 & 26 & 27 & 38 & 100 \\
\hline Mean $=3.870$ & & & & & & \\
\hline Standart Deviasi $=0.869$ & & & & & & \\
\hline
\end{tabular}

Berdasarkan Tabel 7 diketahui bahwa sebagian besar responden memberikan penilaian positif mengenai faktor reliability di Laundry 5Asec. Hal ini dapat ditunjukkan dengan banyaknya responden yang menyatakan setuju dan sangat setuju bahwa karyawan 5Asec selalu tepat waktu dan karyawan 5Asec selalu bertanggung jawab terhadap pekerjaan. Diketahui nilai rata-rata tanggapan responden mengenai reliability adalah 3.870 dengan standart deviasi sebesar 0.869 yang menunjukkan bahwa faktor reliability di Laundry 5 Asec tergolong baik.

\section{Responsiveness $\left(\mathrm{X}_{2}\right)$}

Berdasarkan Tabel 8 diketahui bahwa sebagian besar responden memberikan penilaian positif mengenai faktor responsiveness di Laundry 5Asec. Hal ini dapat ditunjukkan dengan banyaknya responden yang menyatakan setuju dan sangat setuju bahwa karyawan 5Asec cepat dalam merespon permintaan pelanggan, karyawan 5Asec selalu menawarkan bantuan kepada setiap pelanggan dan karyawan 5 Asec dapat menangani setiap keluhan dengan cepat dan tepat. Diketahui nilai rata-rata tanggapan responden mengenai responsiveness adalah 3.564 dengan standart deviasi sebesar 0.768 yang menunjukkan bahwa faktor responsiveness di Laundry 5 Asec tergolong baik.

Tabel 8. Tanggapan Responden Mengenai Responsiveness

\begin{tabular}{lcccccc}
\hline & \multicolumn{5}{c}{ Skor Jawaban } & \\
\cline { 2 - 6 } \multicolumn{1}{c}{ Indikator } & $\mathbf{1}$ & $\mathbf{2}$ & $\mathbf{3}$ & $\mathbf{4}$ & $\mathbf{5}$ & Total \\
\cline { 2 - 5 } & STJ & TS & KS & S & SS & \\
\hline $\begin{array}{l}\text { Kecepatan karyawan 5Asec } \\
\text { dalam merespon permintaan } \\
\text { pelanggan }\end{array}$ & 0 & 14 & 29 & 36 & 21 & 100 \\
$\begin{array}{l}\text { Karyawan 5Asec selalu } \\
\text { menawarkan bantuan kepada } \\
\text { setiap pelanggan }\end{array}$ & 2 & 15 & 24 & 43 & 16 & 100 \\
$\begin{array}{l}\text { Karyawan 5Asec dapat } \\
\text { menangani setiap keluhan } \\
\text { dengan cepat dan tepat }\end{array}$ & 4 & 16 & 29 & 29 & 22 & 100 \\
\hline $\begin{array}{l}\text { Mean = 3.564 } \\
\text { Standart Deviasi=0.768 }\end{array}$ & & & & & & \\
\hline $\begin{array}{l}\text { Sumber: Lampiran 5 dan 6 } 6 \\
\text { Sumburance }\left(\mathrm{X}_{3}\right)\end{array}$ & & & & & & \\
\hline
\end{tabular}

Berdasarkan Tabel 9 diketahui bahwa sebagian besar responden memberikan penilaian positif mengenai faktor assurance di Laundry 5Asec. Hal ini dapat ditunjukkan dengan banyaknya responden yang menyatakan setuju san sangat setuju bahwa informasi yang diberikan para karyawanan 5Asec selalu tepat dan up to date, pengetahuan karyawan 5Asec luas dan tepat, personality karyawan 5Asec sangat memadai dan kinerja karyawan 5Asec meyakinkan. Diketahui nilai rata-rata tanggapan responden mengenai assurance adalah 3.693 dengan standart deviasi sebesar 0.594 yang menunjukkan bahwa faktor assurance di Laundry 5Asec tergolong baik.

Tabel 9. Tanggapan Responden Mengenai Assurance

\begin{tabular}{|c|c|c|c|c|c|c|}
\hline \multirow{3}{*}{ Indikator } & \multicolumn{5}{|c|}{ Skor Jawaban } & \multirow{3}{*}{ Total } \\
\hline & 1 & 2 & 3 & 4 & 5 & \\
\hline & STJ & TS & KS & $\mathbf{S}$ & SS & \\
\hline Informasi yang diberikan para & & & & & & \\
\hline $\begin{array}{l}\text { karyawanan selalu tepat dan up } \\
\text { to date }\end{array}$ & 0 & 3 & 31 & 37 & 29 & 100 \\
\hline $\begin{array}{l}\text { Pengetahuan karyawan luas dan } \\
\text { tepat }\end{array}$ & 0 & 9 & 31 & 46 & 14 & 100 \\
\hline $\begin{array}{l}\text { Personality karyawan 5Asec } \\
\text { sangat memadai }\end{array}$ & 0 & 12 & 33 & 39 & 16 & 100 \\
\hline $\begin{array}{l}\text { Kinerja karyawan } 5 \text { Asec } \\
\text { meyakinkan }\end{array}$ & 0 & 12 & 34 & 35 & 19 & 100 \\
\hline Mean $=3.693$ & & & & & & \\
\hline Standart Deviasi $=0.594$ & & & & & & \\
\hline
\end{tabular}




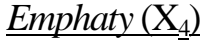

Tabel 10. Tanggapan Responden Mengenai Emphaty

\begin{tabular}{|c|c|c|c|c|c|c|}
\hline \multirow[b]{2}{*}{ Indikator } & \multicolumn{5}{|c|}{ Skor Jawaban } & \multirow[b]{2}{*}{ Total } \\
\hline & 1 & 2 & 3 & 4 & $\begin{array}{c}5 \\
\mathbf{C S}\end{array}$ & \\
\hline $\begin{array}{l}\text { Karyawan 5Asec selalu } \\
\text { membantu dengan tulus }\end{array}$ & 0 & 13 & 29 & 32 & 26 & 100 \\
\hline $\begin{array}{l}\text { Karyawan } 5 \text { Asec selalu } \\
\text { berkomunikasi dengan baik }\end{array}$ & 0 & 12 & 30 & 36 & 22 & 100 \\
\hline $\begin{array}{l}\text { Karyawan } 5 \text { Asec selalu tau } \\
\text { keinginan pelanggan }\end{array}$ & 1 & 13 & 26 & 30 & 30 & 100 \\
\hline $\begin{array}{l}\text { Mean }=3.714 \\
\text { Standart Deviasi }=0.757\end{array}$ & & & & & & \\
\hline Sumber: Lampiran 5 dan 6 & & & & & & \\
\hline
\end{tabular}

Berdasarkan Tabel 10 diketahui bahwa sebagian besar responden memberikan penilaian positif mengenai faktor emphaty di Laundry 5 Asec. Hal ini dapat ditunjukkan dengan banyaknya responden yang menyatakan setuju dan sangat setuju bahwa karyawan 5 Asec selalu membantu dengan tulus, karyawan 5Asec selalu berkomunikasi dengan baik dan karyawan 5Asec selalu tahu keinginan pelanggan. Diketahui nilai rata-rata tanggapan responden mengenai emphaty adalah 3.714 dengan standart deviasi sebesar 0.757 yang menunjukkan bahwa faktor emphaty di Laundry 5Asec tergolong baik.

\section{$\underline{\text { Tangibles }\left(\mathrm{X}_{5}\right)}$}

Tabel 11. Tanggapan Responden Mengenai Tangibles

\begin{tabular}{lccccccc}
\hline \multirow{1}{*}{ Indikator } & \multicolumn{9}{c}{ Skor Jawaban } & & \\
& $\mathbf{1}$ & $\mathbf{2}$ & $\mathbf{3}$ & $\mathbf{4}$ & $\mathbf{5}$ & Total \\
& STJ & TS & KS & $\mathbf{S}$ & $\mathbf{S S}$ & \\
\hline $\begin{array}{l}\text { Tata letak / ruang di 5Asec rapi } \\
\text { dan nyaman }\end{array}$ & 1 & 13 & 38 & 31 & 17 & 100 \\
$\begin{array}{l}\text { Tampilan luar dan dalam 5Asec } \\
\text { menarik }\end{array}$ & 0 & 9 & 28 & 42 & 21 & 100 \\
$\begin{array}{l}\text { Peralatan laundry 5Asec } \\
\text { lengkap }\end{array}$ & 3 & 11 & 31 & 37 & 18 & 100 \\
$\begin{array}{l}\text { Penampilan karyawan 5Asec } \\
\text { rapi dan menarik }\end{array}$ & 4 & 23 & 29 & 26 & 18 & 100 \\
\hline $\begin{array}{l}\text { Mean = 3.530 } \\
\text { Standart Deviasi =0.678 }\end{array}$ & & & & & & \\
\hline Sumber: Lampiran 5 dan 6 & & & & & &
\end{tabular}

Berdasarkan Tabel 11 diketahui bahwa sebagian besar responden memberikan penilaian positif mengenai faktor tangibles di Laundry 5 Asec. Hal ini dapat ditunjukkan dengan banyaknya responden yang menyatakan setuju dan sangat setuju bahwa tata letak/ruang di 5Asec rapi dan nyaman, tampilan luar dan dalam 5Asec menarik, peralatan laundry 5 Asec lengkap, dan penampilan karyawan 5Asec rapi dan menarik. Diketahui nilai rata-rata tanggapan responden mengenai tangibles adalah 3.530 dengan standart deviasi sebesar 0.678 yang menunjukkan bahwa faktor tangibles di Laundry 5Asec tergolong baik.

Loyalitas Pelanggan (Y)

Tabel 12. Tanggapan Responden Mengenai Loyalitas Pelanggan

\begin{tabular}{lcccccc}
\hline \multirow{1}{*}{ Indikator } & \multicolumn{9}{c}{ Skor Jawaban } \\
& STJ & $\mathbf{2}$ & $\mathbf{3}$ & $\mathbf{4}$ & $\mathbf{5}$ & Total \\
& 2 & 13 & 23 & 28 & 34 & 100 \\
\hline $\begin{array}{l}\text { Akan kembali menggunakan } \\
\text { jasa 5Asec }\end{array}$ & & & & & & \\
$\begin{array}{l}\text { Akan tetap memilih 5Asec } \\
\text { sebagai jasa laundry }\end{array}$ & 7 & 19 & 12 & 21 & 41 & 100 \\
$\begin{array}{l}\text { Akan merekomendasikan } \\
\text { 5Asec kepada teman-teman }\end{array}$ & 13 & 4 & 19 & 39 & 25 & 100 \\
\hline $\begin{array}{l}\text { Mean = 3.694 } \\
\text { Standart Deviasi =1.124 }\end{array}$ & & & & & & \\
\hline Sumber: Lampiran 5 dan 6 & & & & & & \\
\hline
\end{tabular}

Berdasarkan Tabel 12 diketahui bahwa sebagian besar responden memberikan penilaian positif mengenai loyalitas pelanggan Laundry $5 \mathrm{Asec}$. Hal ini dapat ditunjukkan dengan banyaknya responden yang menyatakan setuju dan sangat setuju bahwa mereka akan kembali menggunakan jasa 5Asec, mereka akan tetap memilih 5Asec sebagai jasa laundry, dan mereka akan merekomendasikan 5Asec kepada teman-teman mereka. Diketahui nilai rata-rata tanggapan responden mengenai loyalitas pelanggan adalah 3.694 dengan standart deviasi sebesar 1.124 yang menunjukkan bahwa loyalitas pelanggan Laundry 5Asec tergolong tinggi.

\section{Pembahasan}

Berdasarkan pada hasil analisis regresi linier berganda dengan menggunakan uji $\mathrm{F}$, diketahui bahwa secara simultan (serentak) reliability, responsiveness, assurance, emphaty dan tangibles berpengaruh secara serempak dan signifikan terhadap loyalitas pelanggan Laundry 5asec di Surabaya. Dimana reliability, responsiveness, assurance, emphaty dan tangibles memberikan kontribusi terhadap loyalitas pelanggan 5asec Surabaya sebesar $65.6 \%$, sedangkan sisanya sebesar $34.4 \%$ merupakan kontribusi dari faktor lainnya misalnya price, promotion dan product.

Berdasarkan hasil uji t dapat diketahui bahwa variabel reliability merupakan variabel yang berpengaruh paling signifikan terhadap loyalitas pelanggan 5asec Surabaya, dimana pengaruh yang dihasilkan adalah positif. Hal ini mengindikasikan apabila strategi reliability 5asec Surabaya semakin 
baik, maka loyalitas pelanggan 5asec Surabaya semakin meningkat, dengan kata lain pelanggan 5asec Surabaya akan semakin loyal, karena dengan adanya variabel reliability yang baik membuat pelanggan merasa nyaman karena diberikan kepercayaan yang pasti oleh pihak karyawanan 5asec. Hal ini merupakan faktor terpenting bagi pelanggan untuk menjadi loyal. Sepeti dikatakan oleh Parasuraman dalam Tjiptono, (2008, p. 95) bahwa indikator dari reliability yang mencakup tentang konsistensi kerja (performance) dan sifat terpercaya (dependability) yang bersifat positif berpengaruh secara langsung dengan dimensi loyalitas pelanggan yaitu menyatakan tetap memilih merek tersebut (always consume), memberikan rekomendasi kepada orang lain (recommend friend) dan melakukan pembelian terus menerus (continue purchasing). Menurut Tjiptono (2001:85) menyatakan bahwa salah satu faktor yang mendukung terciptanya loyalitas pelanggan adalah faktor kepercayaan, dimana rasa kepercayaan yang diberikan oleh pihak perusahaan memberikan pengaruh efek pada perilaku konsumen yang salah satunya adalah kepuasan konsumen.

Variabel Responsiveness merupakan salah satu aspek distribusi yang sangat penting bagi perusahaan yang bergerak di bidang hospitality seperti restoran, kafe, dan jasa laundry dimana konsumen akan datang pada mereka. Kesediaan karyawan untuk mambantu merupakan salah satu faktor yang mendukung tersiptanya loyalitas pelanggan. Seperti dikatakan (Parasuraman dalam Tjiptono,2008, p. 95): bahwa responsiveness yaitu kesediaan dan kesigapan para karyawan untuk membantu dan melayani pelanggan dengan segera berpengaruh langsung secara positif terhadap loyalitas pelanggan. Karena memberikan nilai plus berupa motivasi khusus bagi para pelanggan untuk menjalin ikatan relasi saling menguntungkan dalam jangka panjang dengan perusahaan. Ikatan inilah yang akan membuat pelanggan menjadi sangat loyal.

Variabel Assurance merupakan salah satu variabel yang penting dalam pengaruh kualitas layanan dalam hal loyalitas pelanggan. Seperti menurut (Parasuraman dalam Tjiptono,2008, p.95) assurance berkenaan dengan pengetahuan dan personality karyawan, serta kemampuan mereka dalam menumbuhkan rasa percaya (trust) dan keyakinan pelanggan (confidence), memberikan kontribusi positif terhadap terwujudnya loyalitas pelanggan. Karena dengan beberapa hal tadi, pelanggan merasa dimengerti dan akhirnya merasa nyaman, sehingga membuat pelanggan tersebut menjadi loyal. Dengan adanya kualitas pengetahuan karyawan yang tepat, maka pelanggan akan merasa yakin untuk menggunakan jasa suatu perusahaan. Oleh karena itu 5asec selalu mengadakan training bagi para karyawannya agar dapat menambah wawasan, dan pengetahuan masing-masing karyawan, sehingga dapat memberikan informasi yang tepat kepada setiap pelanggan

Variabel Emphaty merupakan salah satu variabel yang mendukung dalam pengaruh kualitas layanan bagi loyalitas pelanggan, walaupun memiliki kontribusi prosentase terkecil dalam prosentase pengaruh kualitas layanan terhadap loyalitas pelanggan, tetapi variabel emphaty juga mendukung terciptanya loyalitas pelanggan. Menurut (Parasuraman dalam Tjiptono, 2008, p.95):Emphaty berarti perusahaan memahami masalah pelanggannya dan bertindak demi kepentingan pelanggan, berpengaruh secara positif dimensi loyalitas pelanggan yaitu tetap memilih merek tersebut, merekomendasikannya kepada orang lain dan melakukan pembelian ulang.

Yang terakhir ialah variabel Tangibles merupakan salah satu faktor dominan yang berpengaruh kuat terhadap loyalitas pelanggan. Seperti dikatakan oleh (Parasuraman dalam Tjiptono, 2008, p. 95): tangibles berkenaan dengan penampilan fisik, fasilitas layanan, peralatan/perlengkapan, sumber daya manusia, dan materi komunikasi perusahaan, berkaitan secara langsung dengan indicator-indikator loyalitas pelanggan. Dimana penampilan fisik juga sangat mendukung pelanggan untuk menjadi loyal. 5asec selalu menjaga desain interor dan exterior, serta selalu membentuk atmosphere yang nyaman, sehingga dapat membuat pelanggan menjadi santai berada di laundry 5 asec tersebut.

Variabel reliability merupakan variabel dalam kualitas layanan yang berpengaruh paling dominan dalam loyalitas pelanggan di Laundry $5 \mathrm{asec}$ di Surabaya. Hal ini berarti hipotesis kedua penelitian yang menduga bahwa responsiveness berpengaruh paling dominan terhadap loyalitas pelanggan laundry 5Asec di Surabaya, tidak terbukti kebenarannya. Menurut hasil kuisioner dari para responden bahwa variabel reliability adalah merupakan variable yang berpengaruh paling dominan, dikarenakan dengan adanya rasa percaya yang dimiliki oleh pelanggan akan suatu perusahaan maka pelanggan akan menjadi aman dan nyaman yang berujung dengan melakukan pembelian ulang, sehingga menjadi pelanggan yang loyal. Seperti dikatakan Tjiptono (2001:85) menyatakan bahwa salah faktor yang sangat mendukung terciptanya loyalitas pelanggan adalah faktor kepercayaan, dimana rasa kepercayaan yang diberikan oleh pihak perusahaan memberikan pengaruh efek pada perilaku konsumen, yaitu membuat pelanggan menjadi loyal. 
Hasil analisis di atas menunjukkan bahwa variabel reliability, responsiveness, assurance, emphaty, tangible 5asec Surabaya berpengaruh positif dan signifikan terhadap kepuasan pelanggan. Dengan demikian apabila kualitas layanan di laundry5asec-Surabaya semakin baik, dengan semakin meningkatkan dimensi daripada variabekvariabel kualitas layanan, seperti misalnya peningkatan performance dari para karyawan, semakin memberikan layanan yang yang lebih kepada setiap pelanggan, memberikan inovasi berbeda dari segi kualitas layanan, dan semakin konsisten kinerja karyawan, maka pelanggan akan menjadi semakin loyal terhadap laundry. Oleh karena itu, pihak manajemen 5asec-Surabaya Surabaya harus selalu memperhatikan dan meningkatkan strategi kualitas layanan laundry 5asec Surabaya agar pelanggan akan menjadi semakin loyal. Hal ini berkaitan dengan manfaat dari adanya loyalitas pelanggan yang antara lain adalah membuat hubungan antara perusahaan dan pelanggannya menjadi harmonis, memberikan dasar yang baik bagi pembelian ulang, dapat mendorong terciptanya loyalitas pelanggan, membentuk suatu rekomendasi dari mulut ke mulut (word-of-mouth) yang menguntungkan bagi perusahaan, reputasi perusahaan menjadi baik di mata konsumen, serta laba yang diperoleh dapat meningkat (Tjiptono, 1994, p. 9).

\section{KESIMPULAN DAN SARAN}

\section{Kesimpulan}

Berdasarkan hasil analisa dan pembahasan yang sudah dijelaskan pada bab IV, maka kesimpulan dari penelitian ini adalah sebagai berikut:

1. Diketahui variabel reliability, responsiveness, assurance, emphaty, dan tangibles berpengaruh secara serentak dan signifikan terhadap loyalitas pelanggan laundry 5Asec di Surabaya.

2. Diketahui ternyata variabel reliability merupakan variabel yang berpengaruh paling dominan terhadap loyalitas pelanggan laundry 5Asec di Surabaya.

\section{Saran}

Berdasarkan kesimpulan yang diperoleh, dapat dikembangkan beberapa saran bagi pihak-pihak yang berkepentingan dalam penelitian ini. Adapun saransaran yang dikemukakan adalah sebagai berikut:

1. Hendaknya pihak manajemen 5asec Surabaya selalu berusaha meningkatkan kualitas layanan mencakup 5 (lima) variabel yaitu variabel reliability, rerposiveness, assurance, emphaty, dan assurance agar loyalitas pelanggan semakin meningkat, hal tersebut bisa dilakukan dengan cara menambah jadwal training karyawan, serta meningkatkan konsistensi kinerja karyawan.

2. Hendaknya pihak manajemen 5asec semakin meningkatkan konsisten kinerjanya, serta harus selalu menepati janji yang yang pernah dibuatnya, apabila terpenuhi dapat membuat pelanggan menjadi puas dan akhirnya loyal, sehingga akan menggunakan jasa laundry 5asec secara terusmenerus.

3. Variabel reliability merupakan salah satu variabel yang sangat dominan bagi terbentuknya loyalitas pelanggan, oleh karena itu, hendaklah perusahaan memperhatikan, serta terus meningkatkan faktor tersebut. Karena walaupun variabel reliability kelihatannya tidak terlalu penting, tetapi pada kenyataanya variabel reliabilitylah yang ternyata berpengaruh paling dominan.

\section{DAFTAR PUSTAKA}

Essinger, James \& Wylie, Helen,(2003). Customer loyalty: Devising successful strategies in food and drink.

Gordon, Ian H and Evans. (1992). Competitor targeting: Winning the battle for market and customer share. Canada: National Liberary

Gronroos, C., (2000). Services management and marketing: a customer relatonship management approach. $\left(2^{\text {nd }}\right)$ ed. Chichester: John Wiley \& Sons, Ltd.

Hakim, Abdul dan Kumadji, Srikandi, (1997). Pengantar statistika, Surabaya: CV. Citra Media.

Johnson, D.M., (1997). Customer orientation and market action. Englewood Cliffs, New Jersey: Prentice hall international inc.

Kotler, Philip, (1994). Marketing management: analysis, planing, implementation and control, $\left(8^{\text {nd }}\right)$ ed, International Edition, Englewood Cliffs, New Jersey: Prentice Hall Inc.

Kotler, Philip, and Amstrong Gary, (1996). Principles of marketing, $\left(9^{\text {nd }}\right)$ ed, Englewood Cliffs, New Jersey: Prentice Hall Int, Inc.

Kotler, P., Bowen, J. \& Makens, J. (1999). Marketing for hospitality anf tourism, (International ed), Prentise Hall. New Jersey: Prentice Hall Int, Inc.

Kotler, Phillip, (2000) Marketing management, (The Millenium Edition). New Jersey: PrenticeHall.

Kotler, Philip, (2000). Manajemen pemasaran-analisis, perencanaan, implementasi dan pengendalian, Jakarta: Erlangga. 
Kotler, P., (2002) Manajemen pemasaran Jilid 1, ( $\left.5^{\text {nd }}\right)$ ed. Jakarta: PT. Prehallindo.

Kotler, Philip and Gary Amstrong, (2003). Dasardasar pemasaran., $\left(9^{\text {nd }}\right)$ ed, Jilid I. Jakarta: Indeks Kelompok Gramedia.

Lovelock, C., and Wright, L., (2002). Principle of services marketing and management. New Jersy: Pearson Education, Inc.

Minor, M., \& Mowen, J. (2002). Perilaku konsumen, $\left(5^{\text {nd }}\right)$ ed, Jilid pertama. Jakarta: Erlangga.

Malhotra, N. K., (2004). Marketing reserch: annaplied orientation, $4^{\text {th }}$ ed, New Jersy Prentice Hall.

Prawitra, Teddy, dan Sutrisna, (2001). Kepuasan pelanggan sebagai keunggulan daya saing: Konsep. Jakarta: Indeks Kelompok Gramedia.

Simamora, Henry. (2002), Manajemen sumber daya manusia, Yogyakarta: STIE YKPN.

Sihite, Richard, (1996). Laundry and dry cleaning. Cetakan keempat, SIC, Surabaya: Bumi Pelindo.
Tjiptono, Fandy, (2001). Manajemen jasa, Yogyakarta: Penerbit Andi.

Tjiptono, Fandy, (2004). Strategi pemasaran. Edisi Kedua. Yogyakarta: Penerbit Andi.

Tjiptono, Fandy, (2008). Service management: mewujudkan layanan prima. Yogyakarta: Penerbit Andi.

Umar, Husein, (2001). Riset pemasaran \& perilaku konsumen, Jakarta: PT. Gramedia Pustaka.

Zeithaml, Valerie, Parasuraman A.A. \& Leonard, Berry L., (1990). Delivering quality service: balancing customer perseption \& expectation. Ney York.

Zeithaml, V.A., and Bitner, M.J., (2003). Services marketing: integrating customer focus across the firm, (International Edition), New York: The McGraw-Hill Companies. Inc. 